УДК 615.014:582.929.4

DOI https://doi.org/10.11603/2312-0967.2021.3.12387

\title{
ФІТОХІМІЧНИЙ АНАЛІЗ СПОЛУК ТЕРПЕНОВОЇ ПРИРОДИ В СИРОВИНІ ДЕЯКИХ ПРЕДСТАВНИКІВ ТРИБИ MENTHЕАЕ (РОДИНА LAMIACEAE)
}

\author{
М. І. Шанайда \\ Тернопільський національний медичний університет імені І. Я. Горбачевського МОз \\ України \\ shanayda@tdmu.edu.ua
}

ІНФОРМАЦІЯ

Надійшла до редакції / Received: 05.07.2021

Після доопрацювання / Revised: 15.07.2021

Прийнято до друку / Accepted: 20.08.2021

\section{Ключові слова:}

Dracocephalum moldavica;

Lophanthus anisatus;

Satureja hortensis;

трава;

тонкошарова хроматограсрія;

високоесрективна

рідинна хроматограсрія;

спектрофотометрія.

\begin{abstract}
АНОТАЦІЯ
Мета роботи. Фітохімічний аналіз сполук терпенової природи у траві трьох видів триби Mentheae Dumort. родини Lamiaceae Martinov (Dracocephalum moldavica L., Lophanthus anisatus (Nutt.) Benth та Satureja hortensis L.) хроматографічними та спектрофотометричним методами.

Матеріали і методи. Траву рослин заготовляли на дослідних ділянках у Тернопільській області на початку їхнього масового цвітіння. Ефрірні олії отримували шляхом гідродистиляції. Для ідентифікації терпенових сполук використовували метод тонкошарової хроматограсрії (ТШХ). Компонентний склад тритерпеноїдів визначали методом високоесективної рідинної хроматограсрії (BEPX). Сумарний вміст тритерпеноїдів встановлено спектрофотометрично.

Результати й обговорення. Методом ТШХ встановлено домінуючі компоненти та специфічні «хроматограсрічні відбитки» ефрірних олій для кожного з видів, а також ідентифіковано нелеткі терпенові сполуки їхньої сировини - урсолову кислоту та $\beta$-ситостерол. Методом ВЕРХ встановлено, що урсолова та еускасрова кислоти були основними тритерпеновими сполуками трави усіх досліджуваних видів; еускафова кислота (0,56 \%) превалювала в сировині Satureja hortensis, урсолова (0,21 \%) - у Lophanthus anisatus. Методом спектрофотометрії виявлено зниження сумарного вмісту тритерпеноїдів у напрямі Lophanthus anisatus $(1,67 \pm 0,04 \%)>$ Satureja hortensis $(1,26 \pm 0,03 \%)>$ Dracocephalum moldavica $(1,05 \pm 0,03 \%)$.

Висновки. На основі проведеного фрітохімічного аналізу у траві досліджуваних видів ідентифріковано сполуки терпенової природи, а також встановлено компонентний склад і сумарний вміст тритерпеноїдів.
\end{abstract}

Вступ. Фітохімічне дослідження рослинної сировини є основою для аналізу потенційної ролі окремих груп біологічно активних речовин (БАР) при створенні фрітопрепаратів на їхній основі. На відміну від синтетичних препаратів, фрітозасоби є переважно багатокомпонентними сумішами БАР рослин, тому їх вивчення потребує використання різноманітних методів фрітохімічного аналізу.

Представники триби Mentheae Dumort. підродини Nepetoideae Burnett. родини Глухокропивові
(Lamiaceae Martinov) становлять значний інтерес ceред науковців як цінні джерела БАР терпенової та френольної природи [1-5]. У цій підродині є такі відомі роди офріцинальних лікарських рослин, як Mentha, Melissa, Origanum, Salvia, Thymus тощо [6]. Значну увагу дослідників в останні роки привертає аналіз складу та біологічної активності БАР терпенової природи в сировині неофіцинальних видів ефіроолійних рослин із родів Dracocephalum, Lophanthus

ISSN 2312-0967. Pharmaceutical review. 2021. № 3 
(Agastache), Satureja тощо [1, 4, 7-12], які застосувують у народній медицині різних країн та мають значний терапевтичний потенціал.

Науковці встановили істотні хемотипові відмінності в компонентному складі ефірних олій у межах видів триби Mentheae. Так, О. Ю. Коновалова та співавт. [13] визначили, що домінуючими компонентами ефрірної олії Agastache foeniculum (син. Lophanthus anisatus) при інтродукції в Ботанічному саду імені А. В. Фоміна (м. Київ), незалежно від фрази онтогенезу, були ментон, ізоментон і пулегон. Разом з тим, інтродукований в умовах Тернопільської області хемотип цього виду характеризувався превалюванням естраголу (32,16 \%) і пулегону (20,43 \%) [3]. Румунські дослідники [14] встановили домінування y-терпінену (37,86 \%) в ефрірній олії Satureja hortensis, тоді як у досліджуваного виду вітчизняної заготівлі домінував карвакрол (76,16 \%) [3]. Наявність значної кількості ботанічних і селекційних фрорм та хемотипів у межах видів із цих таксонів привертає значну увагу дослідників до аналізу їхнього хімічного складу. Поєднане використання хроматографрічних методів та спектрофротометрії відкриває можливість провести комплексне фрітохімічне вивчення різних БАР терпенової природи у сировині перспективних представників цієї триби.

Мета роботи - фрітохімічний аналіз сполук терпенової природи у траві трьох представників триби Mentheae (Dracocephalum moldavica L., Lophanthus anisatus (Nutt.) Benth ma Satureja hortensis L.) хроматографічними та спектрофотометричним методами.

Матеріали і методи. Матеріалом для досліджень була трава Dracocephalum moldavica (фріолетовоквіткова фрорма), Lophanthus anisatus (фріолетовоквіткова срорма) та Satureja hortensis, яку заготовляли на дослідних ділянках у Тернопільській області на початку їхнього масового цвітіння. Рослини вирощено із насіння колекції відділу нових культур Національного ботанічного саду імені М. М. Гришка НАН України відповідно до Настанови «Лікарські засоби. Належна практика культивування та збирання вихідної сировини рослинного походження» [15].

Еорірні олії отримували із сировини рослин методом гідродистиляції відповідно до [6]. ТШХ-аналіз ефрірних олій проводили порівняно з розчинами стандартних зразків (С3) сполук - карвакролу, естраголу, геранілацетату, які домінували в їхньому складі, відповідно до результатів попередньо проведеного газохроматографічного аналізу [3]. Для хроматографування застосовували ТШХ-пластини $\mathrm{F}_{254}(20 \times 10$ см, із силікагелем, Merck). Розчинення ефрірних олій і С3 здійснювали в метиленхлориді. Рухома фраза: метиленхлорид. Дериватизацію проводили розчином анісового альдегіду; переглядали пластини при денному світлі.

Для хроматограсрічного аналізу нелетких терпеноїдів здійснювали екстрагування подрібненої трави рослин із використанням 70 \% етанолу. Відважену сировину поміщали в круглодонну колбу та додавали $70 \%$ етанолу (співвідношення сировина-екстрагент 1:20). Спочатку проводили настоювання при кімнатній температурі впродовж 3 год, після чого здійснювали екстракцію на водяній бані при температурі кипіння екстрагенту впродовж 60 хв. ТШХ-аналіз витягів проводили порівняно з розчинами С3 урсолової кислоти та $\beta$-ситостеролу. Рухома фраза: метиленхлорид - метанол (9:1); дериватизація - розчином анісового альдегіду; переглядали ТШХ-хроматограми при денному світлі. Для ВЕРХ-аналізу тритерпеноїдів $70 \%$ етанольні витяги випаровували до сухого залишку у вакуумно-роторному випаровувачі Heidolph Hei-VAP Advantage. Використовували рідинний хроматографр Shimadzu LC20 Prominence [16]; колонка X-Bridge C18 (150 мм × 4,6 мм × 5 мкм); температура колонки - $30{ }^{\circ} \mathrm{C}$; рухома фраза: метанол та 0,2 \% розчин амонію ацетату ( $\mathrm{pH}=6,75)$ у співвідношенні $(8: 2)$; режим елюювання ізократичний. Визначення сумарного вмісту тритерпеноїдів, у перерахунку на урсолову кислоту, проводили з використанням спектрофотометра Hitachi U-2810 згідно з методикою, наведеною в роботі А. С. Нікітіної [1].

Результати й обговорення. Аналіз значень $R_{f} i$ забарвлення зон на ТШХ-хроматограмах есрірних олій досліджуваних видів у присутності достовірних зразків сполук дав змогу виявити їхній домінуючі компоненти та встановити специфрічні «хроматографрічні відбитки» (рис. 1). Так, на хроматограмі ефрірної олії Dracocephalum moldavica було чітко видно інтенсивну фріолетову зону $\left(\mathrm{R}_{\mathrm{f}}=0,51 \pm 0,02\right)$, яка відповідала С3 геранілацетату. У Lophanthus anisatus ідентифріковано яскраву фріолетову зону у верхній третині хроматограми, яка співпала із плямою естраголу $\left(R_{f}=0,72 \pm 0,02\right)$. Червонувато-рожеву пляму карвакролу $\left(R_{f}=0,45 \pm 0,02\right)$ характерної форми виявлено на хроматограмі ефрірної олії Satureja hortensis. Таким чином, представлений ТШХ-аналіз ефірних олій досліджуваних видів можна розглядати як експрес-метод їхньої ідентифрікації - особливо в умовах, коли утруднене проведення досліджень методом газової хроматографії. Варто відзначити, що виявлені в еорірних оліях компоненти мають доведену терапевтичну активність.

У рамках інтерпретації отриманих даних відзначимо, що домінування ароматичного монотерпеноїду карвакролу як сполуки із доведеними антимікробними й антиоксидантними властивостями $є$ характерним, крім Satureja hortensis, також для ефрірних олій інших представників родини Lamiaceae - 3 родів Origanum, Thymus, Monarda тощо [6, 17-19]. Доведено, що ефірна олія Satureja hortensis може накопичувати до 91 \% карвакролу [8]. Загалом, представники родини Lamiaceae характеризуються накопиченням в ефрірних оліях переважно компонентів монотерпенової природи [3], тоді як, напри-

ISSN 2312-0967. Фармацевтичний часопис. 2021. № 3 
Фітохімічні дослідження Phytochemical researches
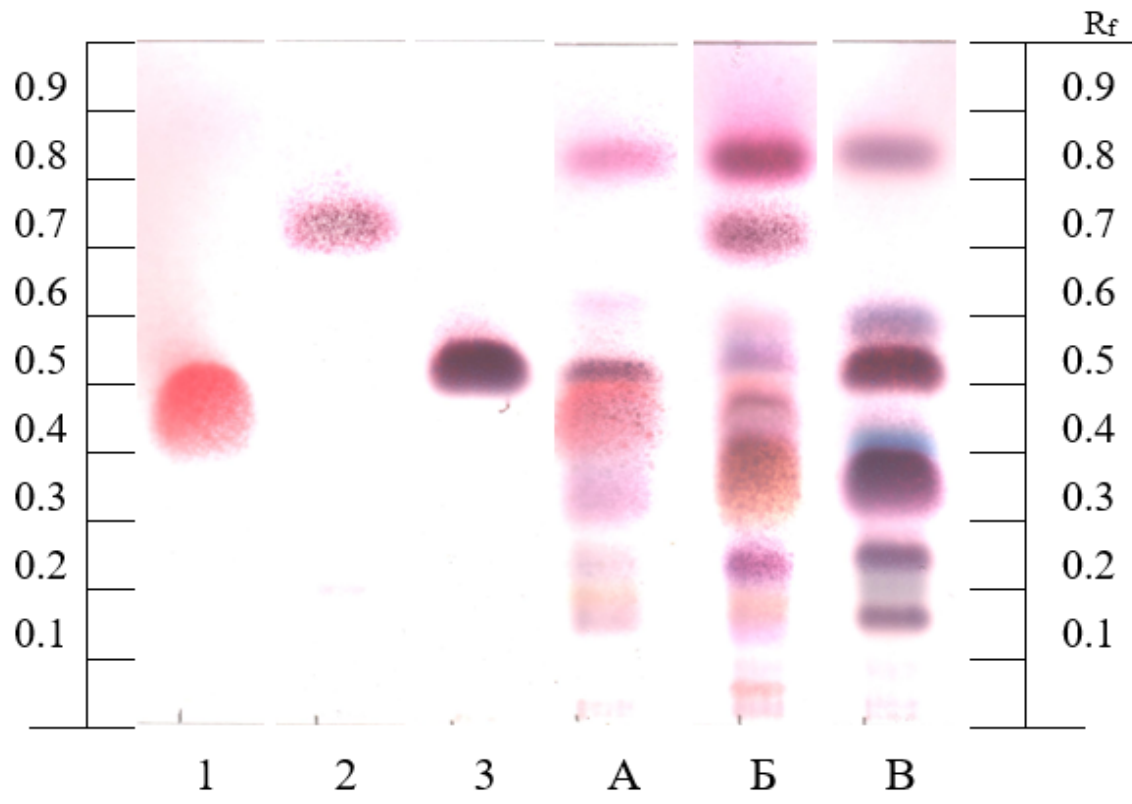

Рис. 1. Тонкошарова хроматографрія розчинів ефірних олій досліджуваних рослин та СЗ терпеноїдів після дериватизації анісового альдегіду розчином P (при денному світлі): 1 - карвакрол, 2 - естрагол,

2 - геранілацетат; A - Satureja hortensis, Б - Lophanthus anisatus, B - Dracocephalum moldavica.

Рухома фраза: метиленхлорид.

клад, родини Asteraceae - сесквітерпеноїдів [20, 21]. Серед десятків проаналізованих Lee та співавт. [19] ефрірних олій максимальний антимікробний ефрект стосовно Escherichia coli мала Origanum vulgare, в складі якої домінував карвакрол, і Thymus vulgaris, в якій переважав тимол. Антимікробні властивості цих монотерпеноїдів науковці пов'язують як із наявністю ароматичного ядра, так і гідроксильної групи [22, 23].

Фенілпропаноїд естрагол (метилхавікол), який належить до домінуючих компонентів досліджуваної нами ефрірної олії Lophanthus anisatus, здатний виявляти противиразковий ефект завдяки цитопротекторній, антиоксидантній та імуномодулюючій дії [24]. Гідролят, який було отримано дослідниками після гідродистиляції ефрірної олії Foeniculum vulgare, характеризувався домінуванням естраголу і фенхону та виявляв значну антимікробну активність [25]. Американські дослідники встановили [26], що трава Agastache foeniculum може накопичувати 88-93\% естраголу. Геранілацетат, який переважав у ефрірної олії Dracocephalum moldavica, яку ми досліджували, а також інших представників роду Dracocephalum [11], широко використовують у парфумерно-косметичній промисловості [27]. Науковці встановили анальгетичні та антимікробні властивості цього ациклічного монотерпеноїду, що відкриває значні перспективи його медичного застосування $[4,28]$.

Для виділення вищих терпеноїдів із рослинної сировини застосовують різні органічні розчинники, проте найбільш екологічно обґрунтованим є використан- ня водно-етанольних сумішей [29]. На основі проведеного ТШХ-аналізу встановлено наявність слабко помітних плям $\beta$-ситостеролу $\left(\mathrm{R}_{\mathrm{f}}=0,75 \pm 0,02\right)$ і урсолової кислоти $\left(\mathrm{R}_{\mathrm{f}}=0,64 \pm 0,02\right)$ в $70 \%$ етанольних витягах трави усіх досліджуваних видів.

Результати BEPX-аналізу тритерпеноїдів у траві досліджуваних видів представлено в таблиці 1. Типову BEPX-хроматограму тритерпенових сполук представлено на рисунку 2 - на прикладі Dracocephalum moldavica. За даними таблиці 1, урсолова та еускафрова кислоти, які $є$ похідними $\alpha$-амірину, були домінуючими тритерпеновими сполуками 70 \% етанольних витягів трави усіх досліджуваних видів. Еускафова кислота (0,56 \%) превалювала у сировині Satureja hortensis, тоді як урсолова $(0,21 \%)$ - у Lophanthus anisatus.

Виявлені у сировині досліджуваних рослин тритерпенові кислоти мають цінні біологічні властивості: протизапальні, спазмолітичні, антимікробні, антиоксидантні, анальгетичні, гепатопротекторні тощо $[9,15,30]$. Дослідники встановили анальгетичний ефект урсолової кислоти, ізольованої 3 екстракту трави Agastache Mexicana [15, 31]. Урсолова кислота, яку було виділено науковцями 3 метанольного екстракту трави Satureja parvifolia, мала виражену антипротозойну активність щодо Plasmodium falciparum [12].

На основі аналізу електронних спектрів світлопоглинання витягів трави досліджуваних рослин в умовах їх спектрофотометричного аналізу було встановлено наявність характерних максимумів при довжині

ISSN 2312-0967. Pharmaceutical review. 2021. № 3 
Фітохімічні дослідження

Phytochemical researches

Таблиця 1

Результати BEPX-аналізу тритерпеноїдів у траві досліджуваних видів триби Mentheae

\begin{tabular}{|c|c|c|c|c|}
\hline \multirow{2}{*}{$\begin{array}{c}\text { Назва } \\
\text { компонента }\end{array}$} & \multirow{2}{*}{$\begin{array}{c}\text { Час } \\
\text { утримання, хв }\end{array}$} & \multicolumn{3}{|c|}{ Вміст сполуки у сировині, \% } \\
\hline & & $\begin{array}{c}\text { Dracocephalum } \\
\text { moldavica }\end{array}$ & $\begin{array}{c}\text { Lophanthus } \\
\text { anisatus }\end{array}$ & $\begin{array}{l}\text { Satureja } \\
\text { hortensis }\end{array}$ \\
\hline Еускафрова кислота & 8,6 & 0,26 & 0,39 & 0,56 \\
\hline Торментинова кислота & 12,5 & 0,02 & 0,03 & 0,04 \\
\hline Бетулін & 14,5 & 0,13 & 0,12 & 0,07 \\
\hline Олеанолова кислота & 16,3 & 0,14 & 0,13 & 0,04 \\
\hline Урсолова кислота & 17,4 & 0,14 & 0,21 & 0,13 \\
\hline
\end{tabular}

so Dracocephalum moldavica, $70 \%$ етанол

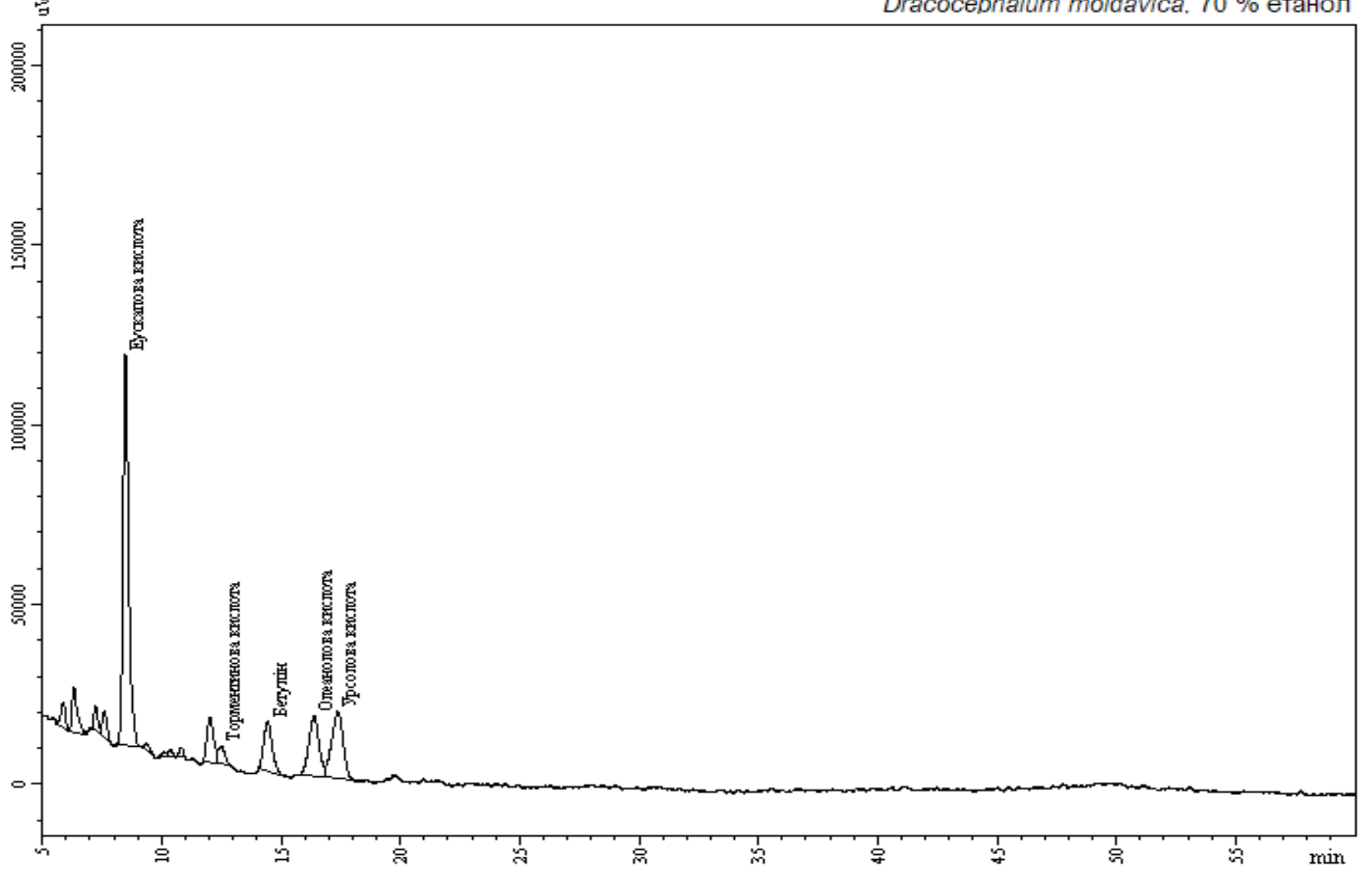

Рис. 2. ВEPX-хроматограма тритерпеноїдів трави Dracocephalum moldavica.

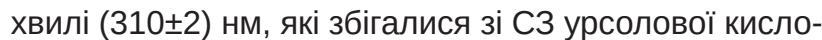
ти (рис. 3 - на прикладі Lophanthus anisatus). У зв'язку з цим, визначення сумарного вмісту тритерпеноїдів у траві рослин здійснювали при цій аналітичній довжині хвилі, у перерахунку на урсолову кислоту.

На основі проведеного спектрофотометричного аналізу встановлено зниження сумарного вмісту тритерпенових сполук у напрямі Lophanthus anisatus $(1,67 \pm 0,04 \%)>$ Satureja hortensis $(1,26 \pm 0,03 \%)>$ Dracocephalum moldavica $(1,05 \pm 0,03 \%)$ (рис. 4).

Згідно 3 літературними даними [1-3, 32-34], у надземних органах різних видів родини Глухокропи- вові тритерпенові сполуки можуть накопичуватись у досить широкому діапазоні - від 0,5 до 5,1 \%. Так, вміст олеанолової та урсолової кислот у листках Rosmarinus officinalis, заготоволених у різних регіонах Китаю, коливався в діапазоні 0,66-1,55 \% і 1,02-2,75\%, відповідно [33]. У траві Ziziphora clinopodioides простежено накопичення 0,76 мг/г та 1,18 мг/г олеанолової та урсолової кислот, відповідно [32]. Вміст урсолової кислоти у сировині Glechoma hederacea та Glechoma hirsuta був у діапазоні 7,17,5 мг/г [34]. Похідні олеанану та урсану, поряд із стеролами, було визначено як основні нелеткі терпенові сполуки сировини Agastache foeniculum [1].

ISSN 2312-0967. Фармацевтичний часопис. 2021. № 3 


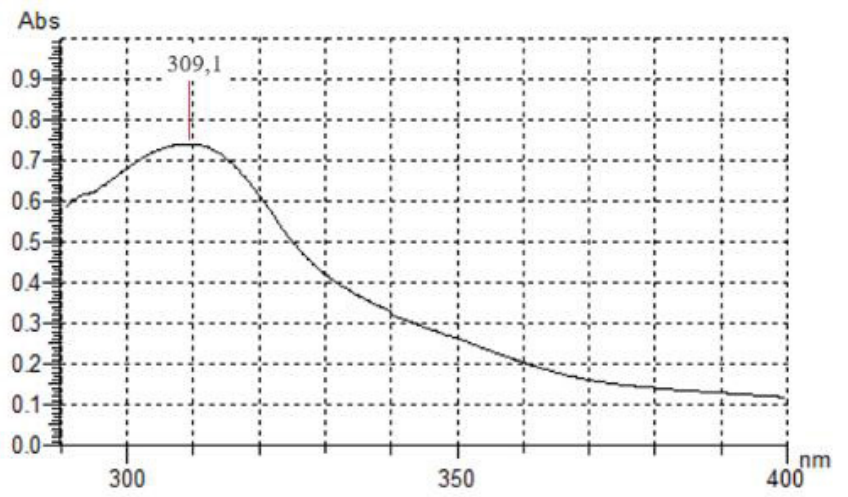

A

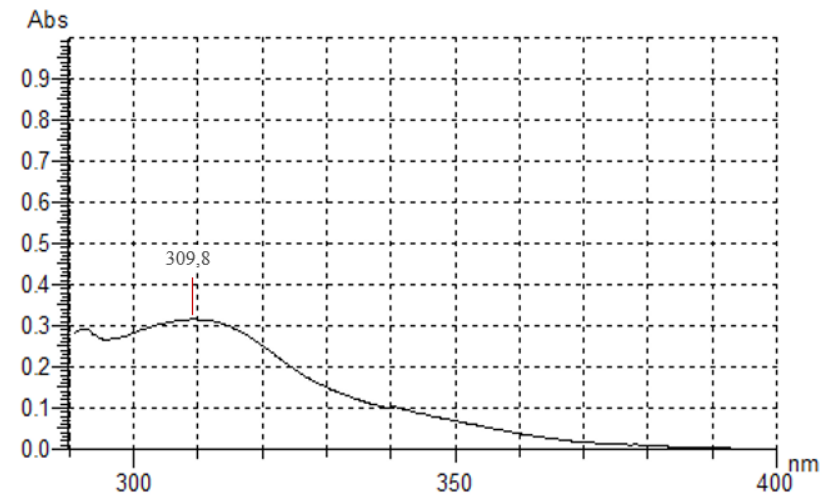

Б

Рис. 3. Електронні спектри поглинання розчину СЗ урсолової кислоти (А) та витягу трави Lophanthus anisatus (Б) в умовах кількісного визначення суми тритерпенових кислот.

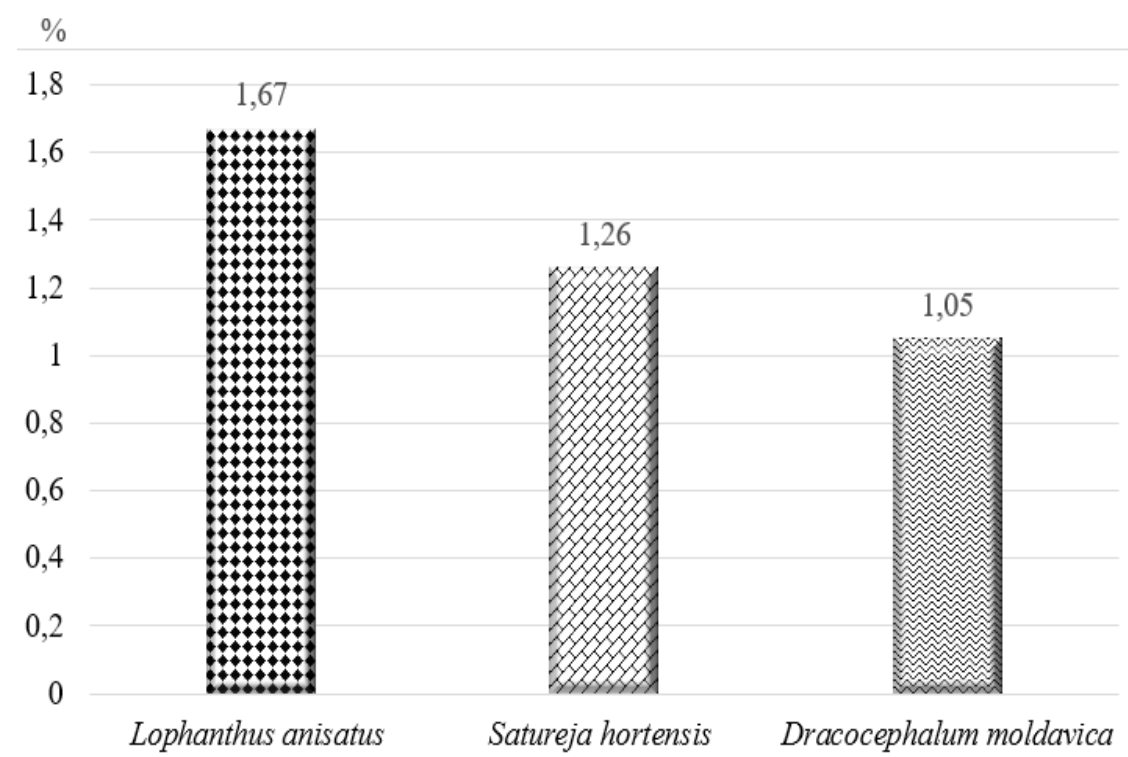

Рис. 4. Порівняльний аналіз сумарного вмісту тритерпенових сполук у траві досліджуваних видів триби Меntheae.

Висновки. 1. На основі проведеного фрітохімічного аналізу трьох представників триби Mentheae (Dracocephalum moldavica, Lophanthus anisatus та Satureja hortensis) в їхній сировині було ідентифріковано сполуки терпенової природи та встановлено компонентний склад і сумарний вміст тритерпеноїдів.

2. Методом ТШХ виявлено домінуючі компоненти та специфрічні «хроматографрічні відбитки» ефрірних олій кожного з видів, а також ідентифріковано нелеткі терпенові сполуки сировини рослин - урсолову кислоту та $\beta$-ситостерол.

3. На основі BEPX-аналізу встановлено, що урсолова та еускафова кислоти переважали в сировині усіх досліджуваних видів. Сумарний вміст тритерпеноїдів, визначений спектрофотометрично, знижувався у напрямі Lophanthus anisatus > Satureja hortensis $>$ Dracocephalum moldavica.

Конфрлікт інтересів: відсутній.

Conflicts of interest: author has no conflict of interest to declare. 
Фітохімічні дослідження

Phytochemical researches

\title{
PHYTOCHEMICAL ANALYSIS OF TERPENIC COMPOUNDS IN THE RAW MATERIALS OF SOME REPRESENTATIVES OF THE TRIBE MENTHEAE (LAMIACEAE FAMILY)
}

\author{
M. I. Shanaida \\ I. Horbachevsky Ternopil National Medical University \\ shanayda@tdmu.edu.ua
}

The aim of the work. Phytochemical analysis of terpenic compounds in the herbs of three representatives of the tribe Mentheae Dumort belonging to the Lamiaceae Martinov family (Dracocephalum moldavica L., Lophanthus anisatus (Nutt.) Benth and Satureja hortensis L.) by chromatographic and spectrophotometric methods.

Materials and Methods. The herbs of plants were harvested from the experimental plots in Ternopil region (Ukraine) at the beginning of their full flowering. Essential oils were obtained using hydrodistillation. The thin layer chromatography (TLC) method was used to identify terpenic compounds. The component composition of triterpenoids was determined by the high performance liquid chromatography (HPLC) analysis. The total contents of triterpenoids were determined spectrophotometrically.

Results and Discussion. The dominant components and specific "chromatographic fingerprints" of the essential oils as well as non-volatile terpene compounds of the herbs such as ursolic acid and $\beta$-sitosterol were determined using TLC method. The HPLC analysis found that ursolic and euscaphic acids were the main triterpenes of the herb of all studied species; euscaphic acid (0.56\%) prevailed in the raw material of Satureja hortensis, and ursolic acid (0.21 \%) in Lophanthus anisatus. A decrease in the total content of triterpenoids in the direction Lophanthus anisatus (1.67 \pm 0.04$) \%$ $>$ Satureja hortensis $(1.26 \pm 0.03) \%>$ Dracocephalum moldavica $(1.05 \pm 0.03) \%$ was determined spectrophotometrically. Conclusions. The conducted phytochemical analysis of herbs of the studied species allowed identifying their terpenic compounds and determining the composition and total contents of triterpenoids.

Key words: Dracocephalum moldavica; Lophanthus anisatus; Satureja hortensis; herb; thin layer chromatography; high performance liquid chromatography; spectrophotometry.

\section{Список бібліографічних посилань}

1. Zielińska S., Matkowski A. Phytochemistry and bioactivity of aromatic and medicinal plants from the genus Agastache (Lamiaceae). Phytochemistry Reviews. 2014. Vol. 13 (2). P. 391-416.

2. Никитина А. С., Попова О.И.Исследование тритерпеновых соединений иссопа лекарственного культивируемого в условиях Ставропольского края. Фундаментальные исследования. 2011. № 1/2. C. 430-432.

3. Шанайда М. І. Фармакогностичне дослідження представників підродини Nepetoideae Burnett. родини Lamiaceae Martinov як джерела одержання лікарських засобів: автореф. дис. на здобуття наук. ступеня д. срармац. наук : 15.00.02 / Львів. нац. мед. ун-т імені Данила Галицького. Львів, 2021. 44 с.

4. Phytochemical, antioxidant and antibacterial properties of Melissa officinalis and Dracocephalum moldavica essential oils. A. Ehsani, O. Alizadeh, M. Hashem et al. Vet. Res. Forum. 2017. Vol. 8 (3). P. 223-229.

5. Karpiński T. M. Essential oils of Lamiaceae family plants as antifungals. Biomolecules. 2020. Vol. 10 (1). P. 103.

6. Державна Фармакопея України: в 3 т. / ДП «Український науково-експертний фрармакопейний центр якості лікарських засобів». 2-е вид. Харків: ДП «Український науково-експертний фрармакопейний центр якості лікарських засобів». 2014. Т. 3. 732 с.

7. Трава чаберу гірського (Satureja montana L., Lamiaceae) як перспективна лікарська сировина для розробки антимікробних та антиоксидантних засобів / Н.І.Гудзь, М.І.Шанайда, Л.В.Свиденко, Я. Шимкова. Вісник фрармації. 2019. № 2 (98). С.4-10.

8. Chemical composition, antioxidant capacity, and thermal behavior of Satureja hortensis essential oil. D. R. Chambre, C. Moisa, A. Lupitu et al. Scientific Reports. 2020. Vol. 10 (1). 21322.

9. González-Burgos E., Gómez-Serranillos M. P. Terpene compounds in nature: a review of their potential antioxidant activity. Curr. Med. Chem. 2012. No. 19 (31). P. 5319-5341.

10. Phytochemical evaluation of tinctures and essential oil obtained from Satureja montana herb. N. Hudz, E. Makowicz, M. Shanaida et al. Molecules. 2020. Vol. 25. P. 4763.

11. Gas chromatography for analysis of essential oils. Characteristics of essential oil of Dracocephalum species and the influence of extraction method on its composition. E. Lemberkovics, A. Z. Kakasy, B. E. Héthelyi et al. Acta Pharmaceutica Hungarica. 2007. Vol. 77 (1). P. 19-27.

12. Triterpenic acids and flavonoids from Satureja parvifolia. Evaluation of their antiprotozoal activity. C. van Baren, I. Anao, P. L. Di Lira et al. Zeitschrift fur Naturforschung. C, Journal of Biosciences. 2006. Vol. 61 (34). P. 189-192.

13. Качественный состав летучихсоединений Agastache foeniculum в онтогенезе / Е. Ю. Коновалова и др. Рецепт. 2017. Т. 20, № 6. С. 544-550.

ISSN 2312-0967. Фармацевтичний часопис. 2021. № 3 
14. A comparative study on the biological activity of essential oil and total hydroalcoholic extract of Satureja hortensis. L. R. A. Popovici, D. Vaduva, I. Pinzaru et al. Exp. Ther. Med. 2019. No. 18 (2). P. 932-942.

15. Настанова «Лікарські засоби. Належна практика культивування та збирання вихідної сировини рослинного походження» : наказ МОЗ від 14.02.2013 p. № 118.

16. Shanaida M., Pryshlyak A., Golembiovska O. Determination of triterpenoids in some Lamiaceae species. Research Journal of Pharmacy and Technology. 2018. No. 7. P. 3113-3118.

17. Хроматографрічний аналіз ефірних олій із трави монарди лимонної різних фаз вегетації / М. І. Шанайда, Л. В. Свиденко, Н. В. Гвоздик, Н. І. Гудзь. Фармацевтичний часопис. 2021. № 1. С. 23-32.

18. Эфирные масла: методы определения подлинности и выявления фральсифрикации. Обзор / И.В.Лапко и др. Аналитика и контроль. 2019. Т. 23, № 4. C. $444-475$.

19. Lee J. H., Kim Y. G., Lee J. Carvacrol-rich oregano oil and thymol-rich thyme red oil inhibit biofilm formation and the virulence of uropathogenic Escherichia coli. J. Appl. Microbiol. 2017. Vol. 123 (6). P. 1420-1428.

20. Determination of essential oil component composition of common sunflower marginal flowers. T. M. Gontova, O. O. Sokolova, A. G. Kotov et al. Research J. Pharm. and Tech. 2018. Vol. 11 (5). P. 1-3.

21. Lange B. M., Turner G. W. Terpenoid biosynthesis in trichomes - current status and future opportunities. Plant Biotechnol. J. 2013. Vol. 11. P. 2-22.

22. Carvacrol and thymol: strong antimicrobial agents against resistant isolates. M. Y. Memar, P. Raei, N. Alizadeh et al. Reviews in Medical Microbiology. 2017. Vol. 28 (2). P. 63-68.

23. Biological activities of essential oils: from plant chemoecology to traditional healing systems. J. Sharifi-Rad, A. Sureda, G. C. Tenore et al. Molecules. 2017. No. 22, 70

24. Estragole prevents gastric ulcers via cytoprotective, antioxidant and immunoregulatory mechanisms in animal models. E. B. Alves Júnior, R. de Oliveira Formiga, C. A. de Lima Serafim et al. Biomedicine \& pharma-

\section{References}

1. Zielińska S, Matkowski A. Phytochemistry and bioactivity of aromatic and medicinal plants from the genus Agastache (Lamiaceae). Phytochemistry Reviews. 2014;13(2): 391-416.

2. Nikitina AS, Popova OI. [Study of triterpenes of medicinal hyssop cultivated in the conditions of the Stavropol territory]. Fundamentalnye issledovaniya. 2011;1/2: 430-2. Russian.

3. Shanaida M.I. Pharmacognostic investigation of representatives of the Nepetoideae Burnett. subfamily of the Lamiaceae Martinov family as a source of herbal medicinal products. Doctor's Extended abstract. Danylo Halytskyi Lviv National Medical University. Lviv, 2021. Ukrainian. cotherapy = Biomedecine \& pharmacotherapie. 2020 Vol. 130. P. 110578.

25. Chemical composition of natural hydrolates and their antimicrobial activity on Arcobacter-like cells in comparison with other microorganisms. D. Šilha, K. Švarcová, T. Bajer et al. Molecules. 2020. Vol. 30, 25 (23). P. 5654.

26. Lawson S. K., Satyal P., Setzer W. N. The volatile phytochemistry of seven native american aromatic medicinal plants. Plants. 2021. Vol. 10 (6), 1061.

27. Engineering Saccharomyces cerevisiae for the production of the valuable monoterpene ester geranyl acetate. T. Wu, S. Li, B. Zhang et al. Microbial Cell Factories. 2018. 17 (1), 85.

28. Antinociceptive activity and redox profile of the monoterpenes (+)-camphene, p-cymene, and geranyl acetate in experimental models. L. Quintans-Júnior, J. C. Moreira, M. A. Pasquali et al. ISRN toxicology. 2013. Vol. 14. P. 459530.

29. Azwanida N. N. A review on the extraction methods use in medicinal plants, principle, strength and limitation. Med. Aromat. Plants. 2015. No. 4. P. 3-9.

30. Dietary ursolic acid improves health span and life span in male Drosophila melanogaster. S. Staats, S., A. E. Wagner, K. Lüersen et al. Biofactors. 2019. Vol. 45. P. 169-186.

31. Spasmolytic and antinociceptive activities of ursolic acid and acacetin identified in Agastache mexicana. M. E. GonzálezTrujano, R. Ventura-Martínez, M. Chávez et al. Planta Medica. 2012. Vol. 78 (8). P. 793-796.

32. Determination of oleanolic acid and ursolic acid contents in Ziziphora clinopodioides Lam. by HPLC method. S. Tian, Y. Shi, Q. Yu, H. Upur. Pharmacogn. Mag. 2010. Vol. 6. P. 116-119.

33. Development and validation of an analytical method based on HPLC-ELSD for the simultaneous determination of rosmarinic acid, carnosol, carnosic acid, oleanolic acid and ursolic acid in rosemary. P. Li, A. Liu, Y. Li et al. Molecules. 2019. Vol. 24(2). P. 323.

34. Simultaneous quantification of ursolic and oleanolic acids in Glechoma hederacea and Glechoma hirsuta by UPLC/ MS/MS. K. Grabowska, P. Żmudzki, D. Wróbel-Biedrawa, I. Podolak. Planta Medica. 2021. Vol. 87 (4). P. 305-313.

4. Ehsani A, Alizadeh O, Hashemi M, Afshari A, Aminzare M. Phytochemical, antioxidant and antibacterial properties of Melissa officinalis and Dracocephalum moldavica essential oils. Vet Res Forum. 2017;8(3): 223-9.

5. Karpiński TM. Essential oils of Lamiaceae family plants as antifungals. Biomolecules. 2020;10(1): 103.

6. The State Pharmacopoeia of Ukraine: Ukrainian Scientific Pharmacopoeia Center of Quality of Medicinal Products. Ed.2. [Державна Фармакопея України: ДП «Український науково-експертний фрармакопейний центр якості лікарських засобів». 2-е вид. Харків: ДП «Український науково-експертний фрармакопейний центр якості лікарських засобів»] Kharkiv: Ukrainian

ISSN 2312-0967. Pharmaceutical review. 2021. № 3 
Scientific Pharmacopoeia Center of Quality of Medicinal Products. 2014. Ukrainian.

7. Hudz NI, Shanaida MI, Svidenko LV, Šimková Ya. Winter Savory (Satureja montana L., Lamiaceae) herb as a perspective medical raw material for development of antimicrobial and antioxidant preparations. Visnyk farmats. 2019;2(98): 4-10. Ukrainian.

8. Chambre DR, Moisa C, Lupitu A, Copolovici L, Pop G, Copolovici DM. Chemical composition, antioxidant capacity, and thermal behavior of Satureja hortensis essential oil. Scientific Reports. 2020;10(1): 21322.

9. González-Burgos E., Gómez-Serranillos M. P. Terpene compounds in nature: a review of their potential antioxidant activity. Curr Med Chem. 2012;19(31): 5319-41.

10. Hudz N, Makowicz E, Shanaida M, Białoń M, Jasicka-Misiak I, Yezerska O, Svydenko L, Wieczorek PP. Phytochemical evaluation of tinctures and essential oil obtained from Satureja montana herb. Molecules. 2020;25: 4763.

11. Lemberkovics E, Kakasy AZ, Héthelyi BE, Simándi B, Böszörményi A, Balázs A, Szoke E. Gas chromatography for analysis of essential oils. Characteristics of essential oil of Dracocephalum species and the influence of extraction method on its composition. Acta Pharmaceutica Hungarica. 2007;77(1): 19-27.

12. van Baren C, Anao I, Di Lira PL, Debenedetti S, Houghton P, Croft S, Martino V. Triterpenic acids and flavonoids from Satureja parvifolia. Evaluation of their antiprotozoal activity. Zeitschrift fur Naturforschung. C, Journal of Biosciences. 2006;61(3-4): 189-92.

13. Konovalova EYu, Gurtovenko IA, Shuraeva TK, Menshova BA, Omelkoviec TC. Qualitative composition of volatile compounds of Agastache foeniculum in ontogenesis. Recept. 2017;20(6): 544-50. Russian.

14. Popovici RA, Vaduva D, Pinzaru I, Dehelean CA, Farcas CG, Coricovac D et al. A comparative study on the biological activity of essential oil and total hydroalcoholic extract of Satureja hortensis L. Exp Ther Med. 2019;28(2): 932-42.

15. Guidelines "Medicines. Good practice of cultivation and harvesting of raw materials of plant origin" (Order N118 MHCU 14.02.2013 y.) Ukrainian.

16. Shanaida M, Pryshlyak A, Golembiovska O. Determination of triterpenoids in some Lamiaceae species. Research Journal of Pharmacy and Technology. 2018;7: 3113-8.

17. Shanaida MI, Svydenko LV, Hvozdyk NV, Hudz NI. Chromatographic analysis of essential oils obtained from the Lemon Beebalm herb in the different vegetation phases Farm chasop. 2021;1: 23-32. Ukrainian.

18. Lapko IV, Aksenova YuB, Kuznecova OV, Vasilevskij SV, Aksenov AV, Taranchenko VF, Antohin AM, Ihalajnen AA. Essential oils: the review of the methods for determining the authenticity and detecting adulteration. Analytics and Control. 2019;23(4): 444-75.

19. Lee JH, Kim YG, Lee J. Carvacrol-rich oregano oil and thymol-rich thyme red oil inhibit biofilm formation and the virulence of uropathogenic Escherichia coli. J Appl Microbiol. 2017;123(6); 1420-8.

20. Gontova TM, Sokolova OO, Kotov AG, Kutsenko SA,
Mashtaler VV. Determination of essential oil component composition of common sunflower marginal flowers. Research J Pharm and Tech. 2018;11(5): 1-3.

21. Lange BM, Turner GW. Terpenoid biosynthesis in trichomes - current status and future opportunities. Plant Biotechnol J. 2013;11: 2-22.

22. Memar MY, Raei $P$, Alizadeh N, Akbari Aghdam M, Kafil HS. Carvacrol and thymol: strong antimicrobial agents against resistant isolates. Reviews in Medical Microbiology. 2017;28(2): 63-8.

23. Sharifi-Rad J, Sureda A, Tenore GC, Daglia M, SharifiRad M, Marco Valussi $M$ et al. Biological activities of essential oils: from plant chemoecology to traditional healing systems. Molecules. 2017;22: 70.

24. Alves Júnior EB, de Oliveira Formiga R, de Lima Serafim CA, Cristina Araruna ME, de Souza Pessoa ML, Vasconcelos RC et al. Estragole prevents gastric ulcers via cytoprotective, antioxidant and immunoregulatory mechanisms in animal models. Biomedicine \& pharmacotherapy $=$ Biomedecine $\&$ pharmacotherapie. 2020;130: 110578 .

25. Šilha D, Švarcová K, Bajer T, Královec K, Tesařová E, Moučková $\mathrm{K}$ et al. Chemical composition of natural hydrolates and their antimicrobial activity on Arcobacterlike cells in comparison with other microorganisms. Molecules. 2020;30,25(23): 5654

26. Lawson SK, Satyal P, Setzer WN. The volatile phytochemistry of seven native american aromatic medicinal plants. Plants. 2021;10(6): 1061.

27. Wu T, Li S, Zhang B, Bi C, Zhang X. Engineering Saccharomyces cerevisiae for the production of the valuable monoterpene ester geranyl acetate. Microbial cell factories. 2018;17(1): 85.

28. Quintans-Júnior L, Moreira JC, Pasquali MA, Rabie SM, Pires AS, Schröder R et al. Antinociceptive activity and redox profile of the monoterpenes (+)-camphene, p-cymene, and geranyl acetate in experimental models. ISRN toxicology. 2013;14: 459530.

29. Azwanida NN. A review on the extraction methods use in medicinal plants, principle, strength and limitation. Med Aromat Plants. 2015;4: 3-9.

30. Staats S, Wagner AE, Lüersen K, Künstner A, Meyer T, Kahns AK et al. Dietary ursolic acid improves health span and life span in male Drosophila melanogaster. Biofactors. 2019;45: 169-86.

31. González-Trujano ME, Ventura-Martínez R, Chávez M, Díaz-Reval I, Pellicer F. Spasmolytic and antinociceptive activities of ursolic acid and acacetin identified in Agastache mexicana. Planta medica. 2012;78(8): 793-6.

32. Tian S, Shi Y, Yu Q, Upur H. Determination of oleanolic acid and ursolic acid contents in Ziziphora clinopodioides Lam. by HPLC method. Pharmacogn Mag. 2010;6: 116-9.

33. Li P, Liu A, Li Y, Yuan B, Xiao W, Liu Z et al. Development and validation of an analytical method based on HPLC-ELSD for the simultaneous determination of rosmarinic acid, carnosol, carnosic acid, oleanolic acid and ursolic acid in rosemary. Molecules. 2019;24(2): 323.

ISSN 2312-0967. Фармацевтичний часопис. 2021. № 3 
34. K. Grabowska, P. Zmudzki, D. Wróbel-Biedrawa, I. Podolak. Simultaneous quantification of ursolic and oleanolic acids in Glechoma hederacea and Glechoma hirsuta by UPLC/MS/MS. Planta medica. 2021;87(4): 305-13.

\section{Відомості про автора}

Шанайда М. І. - д. фрармац. наук, доцент кафедри фрармакогнозії з медичною ботанікою, Тернопільський національний медичний університет імені І. Я. Горбачевського МОЗ України, Тернопіль, Україна. E-mail: shanayda@ tdmu.edu.ua, ORCID 0000-0003-1070-6739.

\section{Information about the author}

Shanaida M. I. - DSc (Pharmacy), Associate Professor of the Department of Pharmacognosy and Medical Botany, I. Horbachevsky Ternopil National Medical University, Ukraine. E-mail: shanayda@tdmu.edu.ua, ORCID 0000-0003-1070-6739. 